\title{
26466 - ELIMINATION OF PREOPERATTIVE TESTING IN AMBULATORY SURGERY
}

\section{Hongbo Yuan PhD; Frances Chung F.R.C.P.C, Santhira Vairavanathan, MD, Ling Yin MD, MSc, David Wong MD. Toronto Western Hospital, Toronto, ON, Canada}

INTRODUCTION: Routine preoperative testing has been criticized as having little impact on periop outcomes. The purpose of this study is to determine whether eliminating preop testing impacts on periop incidence of adverse events in patients undergoing ambulatory surgery.

METHODS: After Institutional Ethics Board approval, patients undergoing orthopedic, plastic, gynecological, general, urology, and ophthalmological (excluding cataract) day surgery were studied. Patients with the following medical conditions were excluded: i) MI, ii) angina, CCS 3, 4, iii) dyspnea, CCS 3, 4, iv) coagulopathy, v) anemia, vi) significant liver disease, vii) significant renal disease, viii) any other new or worsening medical condition that would warrant medical testing even if surgery is not planned. Eligible patients were randomized either to 'no' testing or testing group. Data collectors, patient outcome reviewers and investigators were blind to whether patients received testing or not. Preop tests that were studied: CBC, electrolytes, blood glucose, urea nitrogen, creatinine, ECG and chest X-ray. Sickle cell screening, coagulation tests and pregnancy tests were not studied. Our hospital adopted the Ontario Preop Testing Grid, which lists the indications for each test. For example, ECG is recommended for patients $>45 \mathrm{yrs}$. In the testing group, patients underwent preop testing as per current practice whereas in the 'no' testing group, no testing was ordered. For patients with diabetes, blood glucose was measured on the day of surgery, regardless of the group assignment. The primary outcome measure is the rate of intraop and postop adverse events including MI, myocardial ischemia, congestive heart failure, arrhythmia, hypertension, hypotension, stroke, transient ischemic attack, respiratory failure and other severe complications. Other outcomes were: unanticipated admission and readmission at 7 and 30 days, postoperatively.

RESULTS: A total of 904 patients were recruited; of which, 894 participated (10 withdrawal) in the study. The demographic distributions on age, sex, ASA status were similar between the two groups (see Table). There were no significant differences in the rates of intraop and postop events between the 'no' testing group and the testing group (see Table). Unanticipated admissions were $(\mathrm{P}<0.05)$ higher in the testing group. In the 'no' testing group, none of the events were associated with 'no' testing.

CONCLUSION: Based on the preliminary results of our study, it seems that preoperative testing may be safely eliminated in patients undergoing ambulatory surgery.

*The study is supported by a grant from the Physicians' Services Incorporated Foundation (PSI) 
TABLE Demorgraphics of the patients

\begin{tabular}{|c|c|c|c|c|c|}
\hline Characteristic & \multicolumn{2}{|c|}{$\begin{array}{l}\text { No Testing } \\
\text { No. }(\%)\end{array}$} & \multicolumn{2}{|c|}{$\begin{array}{l}\text { Testing } \\
\text { No. (\%) }\end{array}$} & \\
\hline \multicolumn{6}{|l|}{ Age group (yrs) } \\
\hline $16-39$ & \multicolumn{2}{|c|}{$62(14.2)$} & \multicolumn{2}{|c|}{$65(14.0)$} & \\
\hline $40-59$ & \multicolumn{2}{|c|}{$286(51.4)$} & \multicolumn{2}{|c|}{$233(51.0)$} & \\
\hline$>=60$ & \multicolumn{2}{|c|}{$150(34.4)$} & \multicolumn{2}{|c|}{$159(35.0)$} & \\
\hline Female sex & \multicolumn{2}{|c|}{$187(43.0)$} & \multicolumn{2}{|c|}{$193(42.1)$} & \\
\hline \multicolumn{6}{|l|}{ ASA class } \\
\hline I & \multicolumn{2}{|c|}{$120(28.0)$} & \multicolumn{2}{|c|}{$108(23,6)$} & \\
\hline ॥ & \multicolumn{2}{|c|}{$245(57.1)$} & \multicolumn{2}{|c|}{$275(61.1)$} & \\
\hline III & \multicolumn{2}{|c|}{$51(11.9)$} & \multicolumn{2}{|c|}{$60(13.3)$} & \\
\hline IV & \multicolumn{2}{|c|}{$1(0.23)$} & \multicolumn{2}{|c|}{0.0} & \\
\hline N/A & \multicolumn{2}{|c|}{$12(2.8)$} & \multicolumn{2}{|c|}{$9(2.0)$} & \\
\hline \multicolumn{6}{|c|}{ Rates of intraoperative and postoperative adverse events } \\
\hline \multirow[t]{2}{*}{ Event } & \multicolumn{2}{|c|}{$\begin{array}{l}\text { No Testing } \\
(N=458)\end{array}$} & \multicolumn{2}{|c|}{$\begin{array}{l}\text { Testing } \\
(\mathrm{N}=436)\end{array}$} & \multirow[t]{2}{*}{$\begin{array}{c}\text { Relative Risk } \\
(95 \% \mathrm{Cl})\end{array}$} \\
\hline & $\begin{array}{l}\text { no. of } \\
\text { events }\end{array}$ & $/ 1000$ & $\begin{array}{l}\text { no. of } \\
\text { events }\end{array}$ & $/ 1000$ & \\
\hline Intracperative & 7 & 15.28 & 7 & 16.06 & $0.95(0.37-2.95)$ \\
\hline Postoperative & 10 & 21.83 & 18 & 41.28 & $0.53(0.27-1.24)$ \\
\hline $\begin{array}{l}\text { Unanticipated } \\
\text { admission }\end{array}$ & 2 & 4.37 & 9 & 20.64 & $0.21(0.05-0.97)$ \\
\hline $\begin{array}{l}\text { Hospital readmission } \\
<=7 \text { days }\end{array}$ & 1 & 2.18 & 1 & 2.29 & $0.95(0.06-15.17)$ \\
\hline $\begin{array}{l}\text { Hospital readmission } \\
8-30 \text { days }\end{array}$ & 3 & 6.55 & 5 & 11.47 & $0.57(0.14-2.37)$ \\
\hline Total & 23 & 50.22 & 40 & 91.74 & $0.55(0.13 \cdot 2.40)$ \\
\hline
\end{tabular}

